\section{Hauck and Herring Donate Materials to APSA}

Pendleton Herring, the dean of APSA's Presidents, and Robert J-P. Hauck, APSA Deputy Director, have recently donated important additions to APSA's holdings. Last year, Herring added three more volumes of Puck, volumes 9, 10, and 12 covering much of 1881-82, to the Association's existing collection of volumes 7, 11, 13, 14, and 15. Puck, published in England, long played its role of mischievous sprite pointing a finger at social and political foibles and scandals. With this gift, APSA now has for members' use in the national office volumes published from 188085. Standing with this collection is Herring's additional gift, Satire on Stone: The Political Cartoons of Joseph Keppler, who was the owner and cartoonist in charge of Puck. This volume is particularly helpful in understanding the significance of APSA's Puck collection.

A number of the satirical Puck prints, contributed by Herring and Robert Hauck, adorn the walls of the national office and comprise part of the Pendleton Herring Print Collection entitled "Political Institutions and Behavior as Represented in Art." Herring's interest in political art was in part stimulated while he was writing his classic work, The Politics of Democracy, in which he published photographs of a number of the prints which became the basis of his many gifts of art to APSA. The corpus of APSA's prints was named in honor of Herring, the primary contributor, in 1991.

Recently, Hauck enriched the assembly of materials at the national office by contributing four framed and matted prints and two books to the Association. These include two prints that appeared in Puck in the late 1880 s, "Out of the Frying-pan Into the Fire" and "The Political Courtney"; the Plan of the Senate and House of Representatives of Pennsylvania from the late 1880 s; "The House of Commons, as it appeared in 1741-2" drawn by Gravelot and engraved by W. J. White (1809); and two volumes of James Blaine's autobiography as Speaker of the U.S. House of Representatives. These magnanimous gifts follow in the tradition of Herring and Walter E. Beach and will be enjoyed by political scientists for generations to come.

As Associate and then Deputy Director, Hauck has taken a special interest in maintaining APSA's heritage, including its art and books, its building, and its grounds. In 1996 Hauck helped design and oversaw the renovation of APSA's historic building. In doing so, he researched the history of the building and made sure that the renovation remained faithful to its original architectural elements. Director of the Centennial Campaign, Hauck will help design the new Centennial Center on the fourth floor of the building.

\section{U.S. News Rankings of Political Science Departments Mislabeled, Then Corrected}

APSA was notified by several of its members that the political science specialty rankings in the U.S. News and World Report's 1998 Best Graduate Schools Guidelbook were labeled incorrectly. The rankings, which also appeared on the U.S. News web site, were published in late February. Upon APSA's intervention, U.S. News quickly corrected the labels on its web site. The corrected specialty rankings were published in the March 23, 1998 issue of U.S. News and World Report as well. The guidebooks were distributed to retailers before U.S. News learned of the mistake and, as a result, were not corrected.

APSA informed its members of the labeling error vis PSRT-L and other electronic listservs. APSA is asking members to notify their students of the labeling error. The U.S. News and World Report web site (www.usnews.com) contains the correctly labeled specialty rankings as well as the following Editor's Note alerting individuals to the mistake in the guidebook:

Due to a computer programming error, the political science specialty rankings were incorrectly labeled in U.S. News and World Report's 1998 Best Graduate Schools Guidebook

Guidebook Label Corrected Label

American Politics Comparative Politics International Politics Political Theory
Political Theory International Politics American Politics Comparative Politics

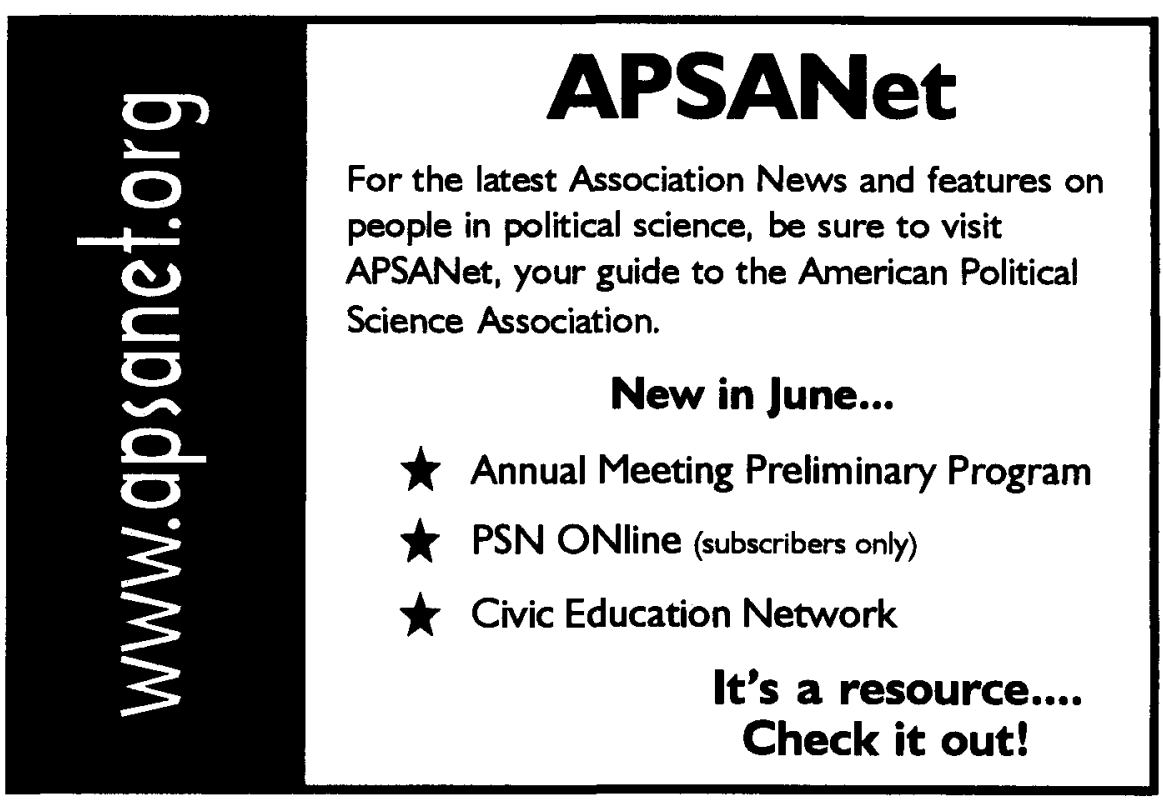

